\title{
CURVE-BILLED THRASHER WINTERS IN ST. CLAUDE, MANITOBA
}

RUDOLF KOES, 135 Rossmere Crescent, Winnipeg, MB R2K 0G1.

The phone rang as I sat on the bench in our front porch, enjoying the spring sun on the afternoon of 20 March 1999. No sense in rushing inside; if it is important, they'll leave a message, I thought. A short time later I checked. Heidi den Haan, who is the librarian at the Delta Waterfowl and Wetlands Research Station when she is not banding birds, had left a message discussing my upcoming visit to the library. Almost as an afterthought she mentioned that there was a Curve-billed Thrasher in St. Claude and that she had left details with Gordon Grieef, a Winnipeg birder. That got my attention!

After a frantic half-hour, while Gord's line was busy, I got through. Robert Jones, Joyce Tomchuk and Heidi, after trying unsuccessfully on the $18^{\text {th }}$, had this morning seen the bird, confirmed the identity, and taken photographs at the feeders of Renee and Louis Hebert of 147 Birch Street. It was too late in the day to try for the bird now, but well before 9:00 a.m. the next morning I arrived, even though the visitor was not expected at the feeder until 11:30. Soon Wayne Neily joined me; we scoured the streets and back-lanes in the area. Pine Siskins, American Goldfinches and a few redpolls attracted our interest, but no thrasher. As the appointed hour neared, more birders arrived and soon the back-lane behind the Hebert home held a crowd of over twenty, while several more birders were inside. Such a gathering would attract attention anywhere and several St. Claude residents came to join us. They knew already about the rarity in town and could fill us in with the details.

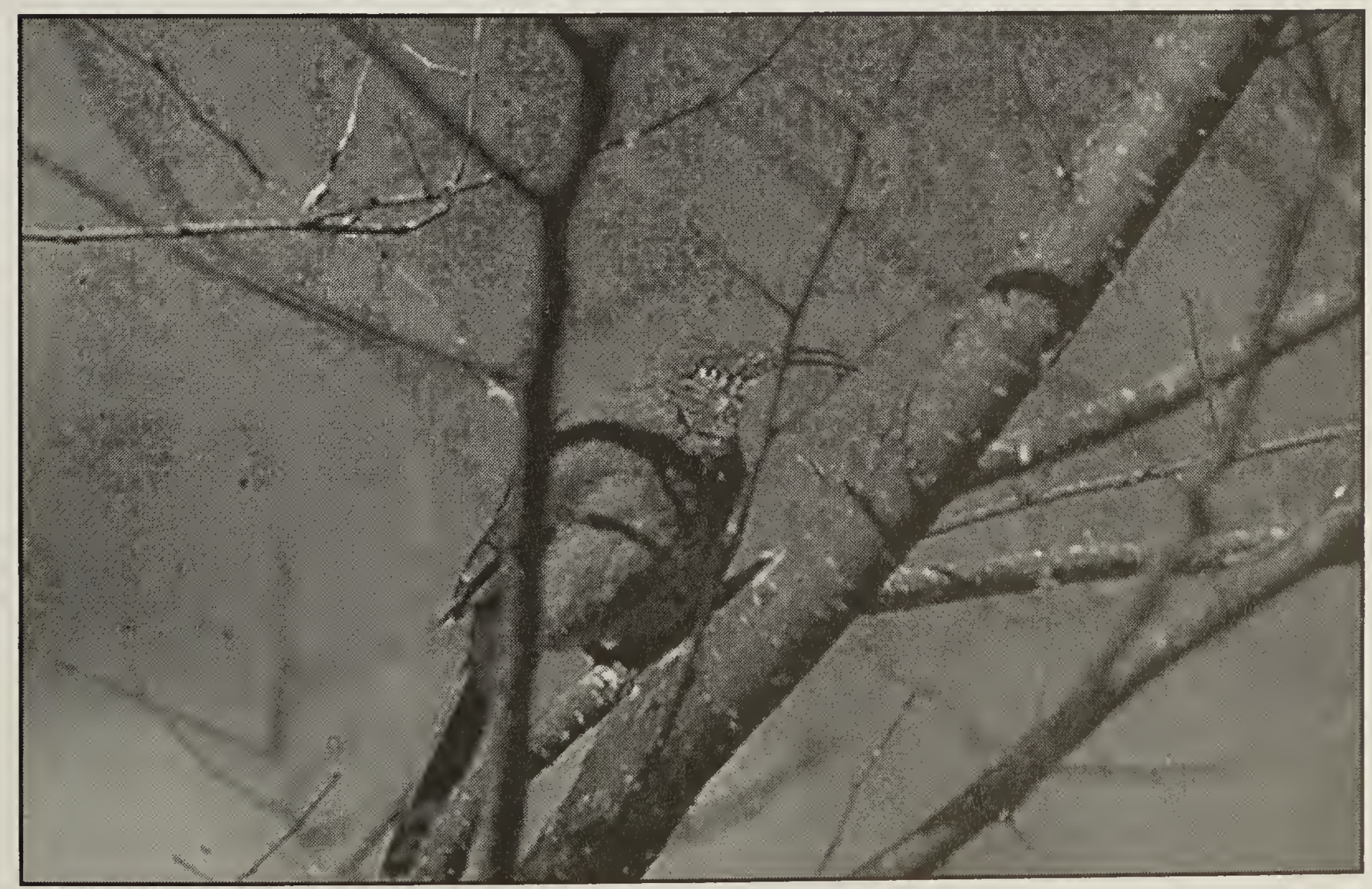


Margaret and Henri Dacquay, nextdoor neighbours of the Heberts, had first noticed the bird in early November 1998. It visited their feeders frequently, until the food ( sunflower seeds and millet) ran out, but there were several other feeders in the area where it was also seen. During the cold weather between mid-December and mid-January it became rather inactive and spent a lot of time perched, fluffed-up, in a large oak between the Hebert and Dacquay homes. With the advent of warmer weather it had once more become quite active. Mr. Dacquay told us that he had not been able to identify the bird, as it was not illustrated in Godfrey's Birds of Canada. ${ }^{3}$ The closest he had come was the Black-billed Cuckoo, so he called it the "cuckoo bird", realizing however the shortcomings of his identification. Eventually Raymond Chattel identified it and through the grapevine the news reached the birding community. A Cooper's Hawk came over, 11:30 came and went.

Then, at 11:35 a.m., there was the thrasher, perched in a tree between the feeders. It surveyed the scene rather warily, and remained in the tree for about a minute. The crowd in the back lane was remarkably restrained, but some excited noises emanated from the house. The thrasher was about the size and shape of a Brown Thrasher. Its overall colouration was a light greybrown, with somewhat paler underparts. The wings showed two rather indistinct whitish wing-bars, the throat was white and the breast dusky grey, with some darker mottling or streaking. This streaking was more pronounced on the lower breast and upper abdomen. The lower abdomen and undertail coverts were pale, with little hint of buffy or rufous as shown in some field guides. ${ }^{5}$ The under-surface of the long tail feathers showed distinct, large areas of white at the tip. The bill was strikingly long, down-curved and black, while the eyes were orange. The bird next hopped onto one of the feeders, gobbled up a few shelled peanuts and flew off into nearby shrubbery.

Although several of us waited for up to half-an-hour, it did not come back. A check of the shrubs revealed nothing and the bird had disappeared as furtively as it had first appeared. In the next few days several others managed to see it, but as the weather warmed, they had to wait longer and longer for its infrequent visits.

The markings on the bird seemed to indicate that it belonged to the "curvirostre" race, except for the breast colouration, which was more like that of the "palmeri" race, as shown in the National Geographic guide. ${ }^{5}$ Whatever the race, the thrasher was a long way from home, its nearest breeding areas being in extreme southern Colorado and the Panhandle of Oklahoma. It has a history of wandering, with sightings reported from as far north as Idaho, South Dakota, Minnesota and Wisconsin. ${ }^{1}$ There was a reported sighting on 27 July 1986 at Raymore in Saskatchewan, but the viewing conditions had been less than ideal and only one observer was involved. ${ }^{4}$ Such sightings have to be considered hypothetical. However, since late August or early September 1998 a Curve-billed Thrasher was present in the town of Barrhead, Alberta, $100 \mathrm{~km}$ northwest of Edmonton. Like the St.Claude bird, it was not identified until much later, early winter in this case. ${ }^{2}$ It attracted a lot of attention and listers from across Canada came to visit. It, too, survived the winter.

It is difficult to attribute the presence of the two birds to any single phenomenon. Much of the American Southwest experienced a dry summer, but as the thrashers apparently arrived 
at different times, this may have had little to do with it. Similarly, no single storm with southerly winds could account for this. Most likely, it was simply a matter of sheer, amazing coincidence.

If accepted by the provincial bird records committees, these two occurrences will represent the first confirmed records for Canada.

\section{Acknowledgements}

I would like to thank Renee and Louis Hebert and Margaret and Henri Dacquay for helping the thrasher survive the Manitoba winter. Thanks also to Heidi den Haan for informing members of the Manitoba Rare Bird Alert, to Dennis Fast for the use of one of his photographs of the bird and to Bob Nero for urging me to write this note.
1. AMERICAN ORNITHOLOGISTS' UNION. 1998. Check-List of North American Birds. $7^{\text {th }}$ edition. American Ornithologists' Union, Washington, D.C. p.520.

2. BAIN, M., and D. SHANAHAN (eds.). 1999. Cross Canada Round-Up, Birders Journal $7: 274$.

3. GODFREY, W.E. 1986. The Birds of Canada. Revised Edition. National Museums of Canada, Ottawa.. 595 pp.

4. GOLLOP, B. 1986. The Nesting Season: Prairie Provinces Region, American Birds 40: 1219.

5. SCOTT, S.L. (ed.). 1983. Field Guide to the Birds of North America. National Geographic Society, Washington, D.C. pp. 338-339.

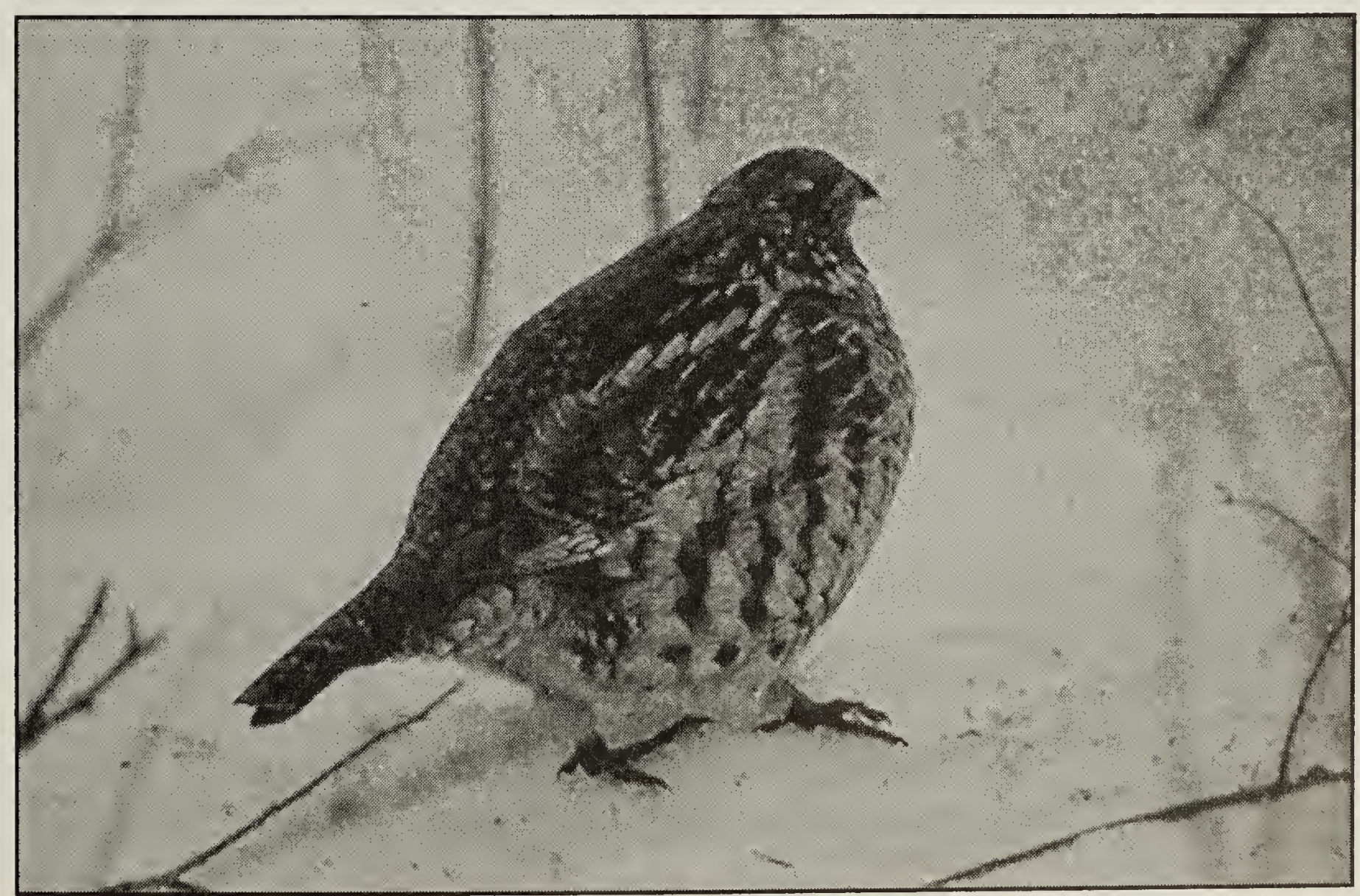

